Original Research

\title{
Innovation Support and Eco-Innovation in the Slovak Republic in the Intentions of Sustainable Development
}

\author{
Peter Malega ${ }^{1}$, Milan Majerník ${ }^{2}, V$ ladimír Rudy ${ }^{1}$, Naqib Daneshjo ${ }^{3 *}$ \\ ${ }^{1}$ Technical University of Kosice, Faculty of Mechanical Engineering, Institute of Management, \\ Industrial and Digital Engineering, Slovak Republic \\ ${ }^{2}$ Research Institute of Commerce and Sustainable Entrepreneurship, Faculty of Commerce, University of Economics \\ in Bratislava, Slovak Republic \\ ${ }^{3}$ Faculty of Commerce, University of Economics in Bratislava, Slovak Republic
}

Received: 4 September 2020

Accepted: 26 November 2020

\begin{abstract}
The Slovak Republic has a precisely established system of institutional support for innovation, which provides a wide system of opportunities for innovation development. Nevertheless, the Slovak Republic is in the last place in the innovation application within the EU, while the biggest problem seems to be the insufficient connection between R \& D on the one hand and companies that could apply new ideas in practice on the other hand. Another big problem is the system of innovation funding, which is a big problem in Slovakia, especially at this time (consequences of the Covid-19 pandemic). Eco-innovation is now an integral part of business strategy in all developed countries. The Slovak Republic is on the last places in EU in this indicator, as the funding of eco-innovations is even more complicated due to the financing of "classic" innovations. Nevertheless, there are several successful eco-innovation projects in Slovakia, which we can consider as a contribution to sustainable development. The eco-innovation index of Slovakia shows that the Slovak Republic belongs to the group of catching-up countries and there is a huge space for improvement, which will probably be used largely in the near future.
\end{abstract}

Keywords: innovation, institutional support for innovation, eco-innovation, sustainable development, Slovak republic

\section{Introduction}

The innovation is in principle a new idea, respectively the process of implementing something new

*e-mail: daneshjo47@gmail.com

that changes the current situation, brings improvements of existing products, services or business activities [1-5]. Innovation is the result of a combination of individual or group innovative competence to adapt to the requirements of the social situation (with innovative behavior) and innovative motivation (corresponding to the willingness of the individual to adapt to innovation and act in accordance with the new situation). 
Innovation plays an important and dual role, mainly as a significant source of uncertainty and change in the environment, and as a significant competitive resource within the company [6-9].

The burden on the environment by industrial activity and the depletion of natural resources by companies also reflects in environmental regulations through international, European and national environmental policies. One of its tools is also eco-innovation. Eco-innovation is one way to improve environmental protection and the efficient used resources of the economy, thus contributing to increasing competitiveness and sustainable development. This we can achieve through development and implementation of new technological and nontechnological solutions, creation of new approaches to doing business or the way of consumption and usage of goods and services. However, the current rate of eco-innovation in enterprises is generally less than optimal, and there is potential to increase ecoinnovation to increase resource productivity and competitiveness and to promote environmental protection and sustainable development.

\section{Material and Methods}

This paper aims at innovation support and ecoinnovation in the Slovak Republic in the intentions of sustainable development, so it is necessary to deal with the innovation support scheme in Slovak Republic that would be complied based on the synthesis of knowledge and information about innovation support that Slovak Republic uses for over 5 years.

\section{Institutional Systems and Tools to Support Innovation in the Slovak Republic}

Developing innovation policies around the world is an important component of institutional systems and support tools. Companies, and in particular SMEs as the largest group, can use a wider portfolio of supporting institutional forms and systems to increase their innovation potential. The most important are:

1. Business clusters,

2. Business incubators,

3. Science-technology parks,

4. Technology platforms.

1. Business clusters - are defined as geographical concentrations of interconnected companies, specialized suppliers, service providers, companies in related industries and connected institutions (such as universities or trade associations) that compete with each other in a particular territory, but also cooperate with each other. Clusters integrate:

- supplier-customer relations,

- may have joint purchase of inputs and distribution channels,
- common technologies,

- development activities,

- marketing,

- common labour market.

2. Business indicators - are organizations/institutions aimed at creation of favourable and supportive environment for start-ups. It provides comprehensive support for small start-ups such as space for their operation, advisory and consulting activities, access to risk capital, and contact with customers, mediation of accounting, legal and financial services. The main role of business incubators is to create successful companies that leave the program only when they become financially independent and are able to operate independently. After the beginning of their activities, they usually move to other business premises - technological innovation centres, or science-technology parks, etc.

3. Science-technology parks - are institutions oriented in the field of science, technology and innovative business. They use their know-how to create conditions for the dynamic development of the innovative companies activities, to ensure the transfer of technologies and education for innovative entrepreneurship. Their basic functions are:

- Incubation,

- Innovation.

The aim is the support of the commercial implementation of research and development results in the form of small and medium enterprises (SME). The science-technology park is closely connected with one or more science and research institutions (universities, academies and others). The founders of the science-technology park are state and regional authorities, universities, and research and development organizations, industrial enterprises, chambers of commerce, financial institutions, private companies, associations and federations. We distinguish three main forms of science-technology parks:

- Science parks (centres),

- Technology parks,

- Business and innovation Centers.

4. Technology platforms - bring together industrial enterprises, research and financial institutions, national public administrations, user and consumer associations involved in research, development and innovation in strategically important technological areas. The aim of this configuration is to create a medium-term to long-term vision of future technological development.

An overview of organizational forms for the support of innovation in Slovak Republic is described in more detail Table 1.

\section{The Current State of Innovation in Slovak Republic}

It is clear, that Slovak companies (like all other companies) are also forced to innovation, because 
Table 1. Overview of organizational forms to support innovation.

\begin{tabular}{|c|c|}
\hline Organizational form & More detailed division of the organizational form \\
\hline \multicolumn{2}{|l|}{ Technology platform } \\
\hline $\begin{array}{l}\text { Research and development } \\
\text { (R \& D) centre }\end{array}$ & $\begin{array}{l}\text { - Research institutes, } \\
\text { - National research and development centres, } \\
\text { - Centre of excellence, } \\
\text { - Technology transfer centre. }\end{array}$ \\
\hline \multicolumn{2}{|l|}{ Technology centre } \\
\hline \multicolumn{2}{|l|}{ Science-technology park } \\
\hline \multicolumn{2}{|l|}{ Business incubator } \\
\hline \multicolumn{2}{|l|}{ Business cluster } \\
\hline Newly established organizational units & $\begin{array}{l}\text { - Spin-off companies, } \\
\text { - Start-up companies. }\end{array}$ \\
\hline Strategic service centres & $\begin{array}{l}\text { - Centres for entrepreneurs, } \\
\text { - Regional consulting and information centres, } \\
\text { - Business innovation centres, } \\
\text { - First contact centres. }\end{array}$ \\
\hline \multicolumn{2}{|l|}{ University centres } \\
\hline \multicolumn{2}{|l|}{ Business entities } \\
\hline Internet information portals in the field of innovation & \\
\hline
\end{tabular}

of growing competitive pressure. Entrepreneurs have to innovate to survive in growing competition. Slovakia's entry to the European Union (EU) and the removal of protective barriers, as well as changes in global trade due to globalization, have contributed to increasing competition in the market. On the other hand, entrepreneurs want to innovate, because of opening new business opportunities. However, working towards innovation that would significantly improve the company's market position is not easy. There are several reasons for this fact.

It can be stated that in Slovakia there is no effective connection and communication between R \& D on the one hand and companies that could use this knowledge on the other hand. Based on a survey of innovation potential carried out regularly by Slovak Business Agency, many enterprises are not yet ready to accept innovations. Their acceptance is also complicated due to the low level of education of employees, while small companies, in particular, have not greater managerial experience.

Another big problem is the fact that Slovak R \& D is underfunded and itself faces several problems. The development of innovative activities is also problematic due to the existing business culture - companies do not like to enter into risky business activities.

The big problem is also the lack of resources to finance innovation. In principle, commercial banks find their financing too risky. Venture capital funds are a better solution in this problem. However, so far in Slovakia, private risky investors have not been very willing to invest in the initial stages of companies, i.e. in seed and start-up activities. In practice, Slovak
Business Agency has the greatest experience with risk financing in Slovakia. Seed Capital Company, a company founded by Slovak Business Agency, has been investing in the share capital of start-ups for more than ten years.

The main causes of the poor state of innovation in the Slovak republic can be considered a weak research base without specific goals, lack of large companies that invest in research, ineffective support from the public sector, low motivation of researchers, etc.

Based on the document approved by the European Council entitled "A strategy for smart, sustainable and inclusive growth - EUROPE 2020", which contains three complementary priorities to meet citizens' quality of life and standard of living:

1. creation of economy based on knowledge and innovation,

2. support of the greener and more competitive economy, which uses resources more efficient,

3. support of the economy with a high employment rate, which ensures social and territorial cohesion.

The most important goal of its economic policy considers the Government of the Slovak Republic to create preconditions for increasing the quality of citizens' life and their standard of living through restoring the growth of the domestic economy and increasing competitiveness by increasing the innovation performance of the Slovak Republic.

Taking into account the above mentioned facts, it is necessary to think about the fact that the industry (especially the automotive industry, which now consists of 4 car plants), forming the backbone of the Slovak economy, is facing a challenge arising from the European 
directive on industrial emissions, which will require significant investment in production sustainability. In such case, innovations are the opportunity to ensure the most efficient return on investment in the direction of maximum recovery of input materials and energy.

Another problem is now the automotive industry, because of the pandemic Covid-19. Car production in Slovakia increased slightly in 2019 and set a record. In total, more than 1.1 million cars were produced, compared to 1.09 million in 2018. Slovakia thus maintained its position as a world No. 1 in car production per capita.

The automotive industry is still the main driver of the Slovak economy. The share of the automotive industry in the performance of industry reached $49.5 \%$ in 2018. In connection with the spread of the deadly coronavirus Covid-19, the risk of decreasing of the entire automotive industry (not only in Slovakia) also increased significantly. According to experts, the negative effects on the Central European economies (including the Slovak economy) will be significant.

As in 2019, the automotive industry faced many challenges and obstacles. It was caused, because of the overall slowdown in the global economy. Car sales in major world markets decreased. Several experts from insurance companies expect that by the end of 2020, the production of this sector worldwide will start to decrease by about $75 \%$. Ultimately, the crisis in the automotive industry is affecting $50 \%$ of industrial production in Slovakia, including a number of smaller companies. It is clear that the new start in the automotive industry is and will be gradual, and it is therefore important for car manufacturers to realize that now more than ever, the customer is the decisive element. Many car manufacturers therefore decided to respond to the current situation in the world and launched the so-called "contactless" test drives and "door to door" car delivery, began working on special "disinfected" vehicles with drone delivery of keys to buyers, or even testing a system to perfume vehicle models with the aroma of traditional Chinese medicine. Despite the current problems, automotive industry in Slovakia is expected to remain a priority sector in next years.

The biggest challenge facing developing countries (including Slovakia) and the EU as a whole in the field of innovation at present is the inability to fully use and share the results of R \& D and subsequently to translate them into economic and social values [10-12]. The gap between research results and their application in practice is still large.

In order for the Slovak economy to start developing in a positive direction in the future, it will be necessary to $[13,14]$ :

- gradually solve issues related to low level of investment in science, $\mathrm{R} \& \mathrm{D}$ and innovation in relation to developed EU countries,

- eliminate the disproportions of the previous period, when mainly money from the EU structural funds were used to support the development of innovation,

- improve cooperation between knowledge providers and their recipients in all sectors,

- create conditions from the part of public institutions to ensure effective support of selected companies that perform industrial R \& D.

Support in the Field of Innovation in the Slovak Republic in the Intentions of Sustainable Development

State support for innovation in developed economies is not unique. State support is a guarantee of the projects quality for the entry of private investors, especially in the case of breakthrough technologies that are capital intensive. Countries such as Austria, Estonia, Portugal and Poland strongly support innovation not only financially, but also through a legislative environment favourable to innovation. This environment consists of e.g. the simplicity of new business starting, tax benefits to support innovation, E-government that is effective and functional, or startup visions, which allow innovators from outside the EU to develop their ideas

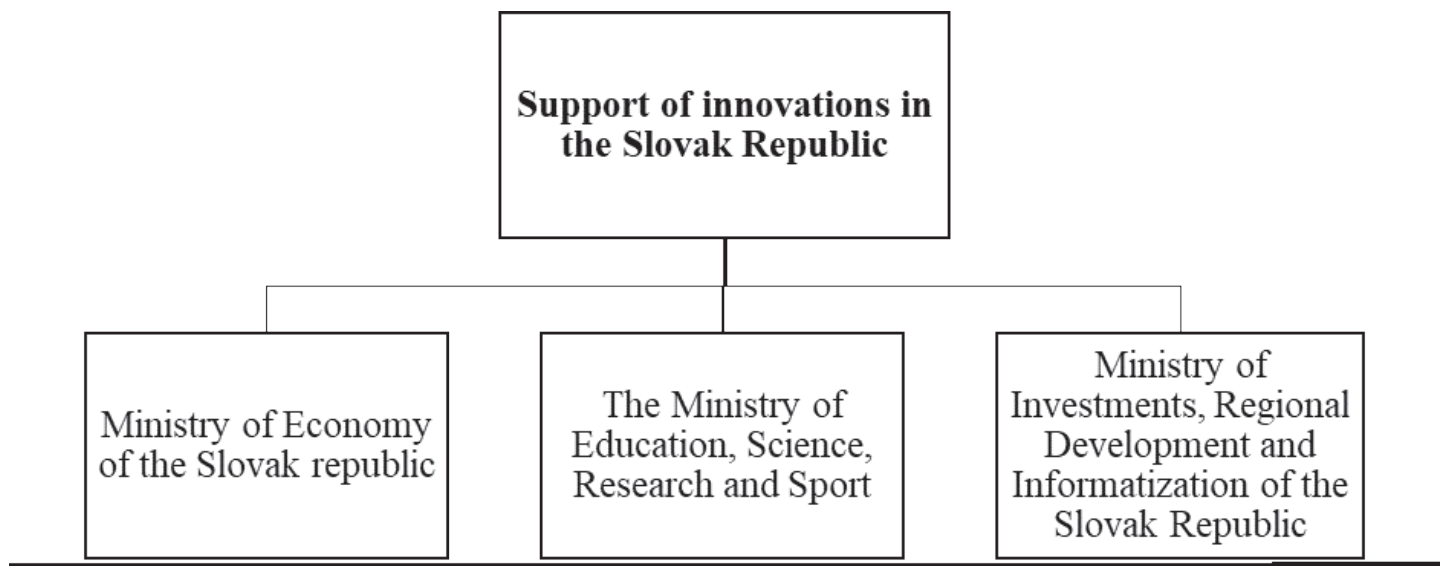

Fig. 1. Innovation support system in the Slovak Republic. 
(for example in Estonia or Portugal). This makes these countries an attractive destination for technological talent, as well as for private investors.

In Slovakia, support for innovation is fragmented. We can state that it belongs under three ministries, namely Ministry of Economy, Ministry of Education, Science, Research and Sport and The Ministry of Investments, Regional Development and Informatization of the Slovak Republic (Fig. 1). In the previous time, there were many uncertainties in the area of competencies, funding and provided institutional support, but now the Ministry has already precisely defined its competencies.

In addition to these organizations, several other organizations in the Slovak Republic specialize in innovation respectively focus on promoting innovation.

In addition to organizations that belong under the state, also other support instruments belong under the $\mathrm{EU}$, or function as non-governmental organizations respectively agencies within the Slovak Republic.

4. The Ministry of Economy of the Slovak republic

The Slovak Republic, as a member state of the EU, is committed and obliged to develop a unified Smart Specialization Strategy, as a starting document from ex-ante conditionalities for the Multiannual Financial Framework 2014-2020. In the conditions of the Slovak Republic, this strategy must not only meet the priorities of the Europe 2020 Strategy, including its key initiatives, but also define measures to meet the objectives of the National Reform Program and the specific recommendations of the Council for the
Slovak Republic.

A. Strategies and policies

a. Research and innovation strategy for intelligent specialization in the Slovak Republic (RIS3).

RIS3 represents the basic framework strategic document for the support of research and innovation in the programming period 2014-2020 and is the basis for the creation of operational programs. At the same time, it is a key document focused on sustainable economic growth and increasing employment in Slovakia through targeted support for research and innovation and achieving critical mass in individual strategic priorities, while taking into account regional specifics.

The task of RIS3 is to define the vision; goals and measures based on a comprehensive analytical part and set priorities of economy and R \& D of the Slovak Republic, taking into account the principles of smart, sustainable and inclusive growth to strengthen Slovakia's competitiveness. The goals of RIS3 are:

- deepen the integration and anchoring of key industrial branches that increase local added value, through the cooperation of local supply chains and the support of their networking,

- increase the contribution of research to economic growth through global excellence and local relevance,

- create a dynamic, open and inclusive innovative society as one of the prerequisites for improving the quality of life,

- improve the quality of human resources for innovative Slovakia.

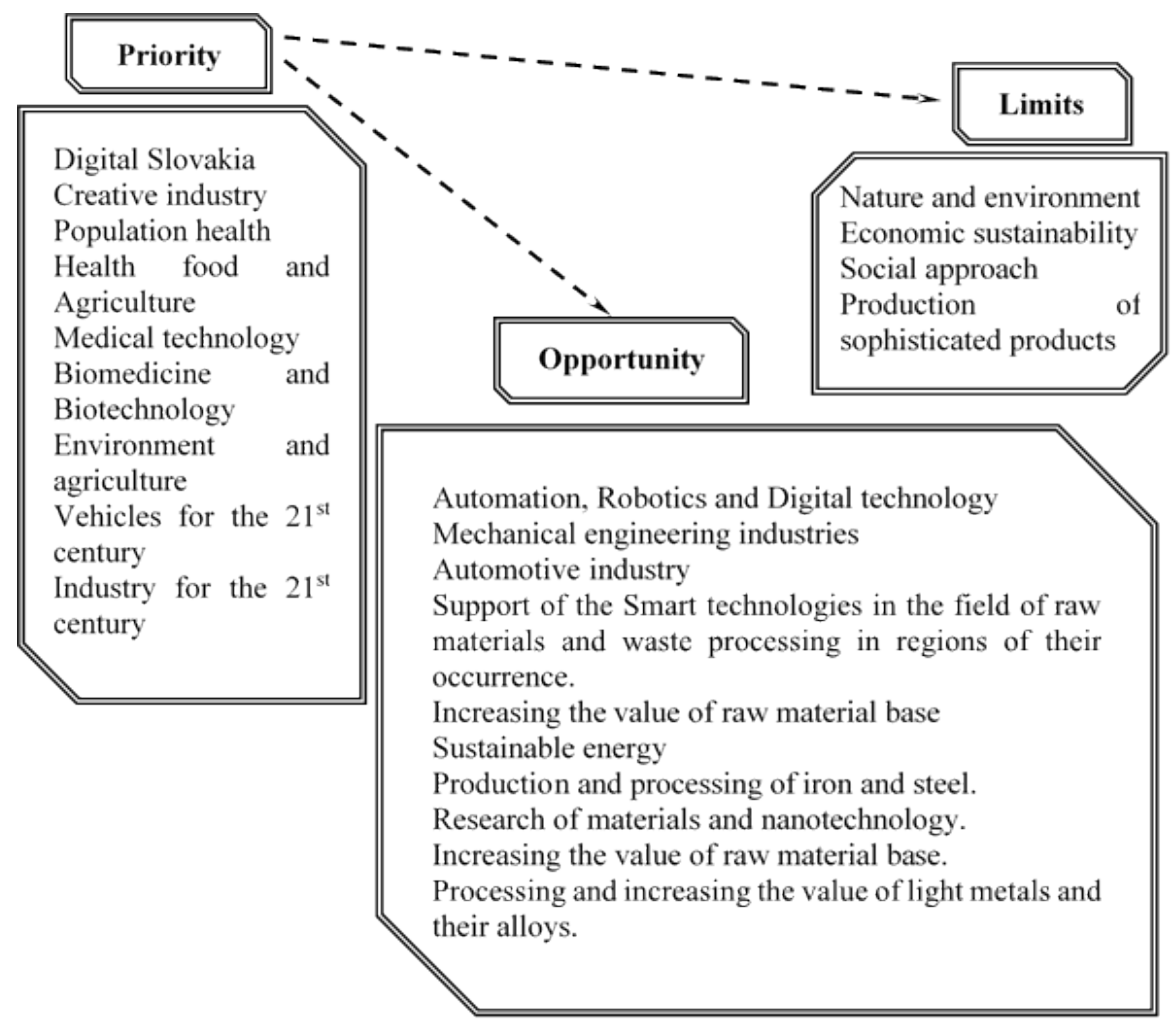

Fig. 2. Innovation support system in the Slovak Republic. 
Within RIS3 was created a methodology for creation of smart specialization domains. The domains were created based on the intersection of economic and research specialization of the Slovak Republic (Fig. 2).

b. Action plan and the concept of intelligent industry.

The goal of Action plan is to support industrial companies, service and trade companies, regardless of their size, aimed at creation of better conditions for the implementation of digitization, innovative solutions and increased competitiveness. This is realized through reducing bureaucracy, amending of legislation, defining standards, changing training programs and the labour market, co-financing of the research, etc. The action plan provides a set of 35 measures that should be implemented by the end of 2020 .

If we want to deal with the issue of Smart industry, it is necessary to focus on Industry 4.0 [15].

The concept of Intelligent Industry has a clear goal - to convince the public about the necessity for concrete actions through recommendations that will maintain the position of Slovak companies on the industrial map of Europe and in global structures [16, 17].

The concept of Intelligent Industry for Slovakia is an expected response to the fourth industrial revolution (Industry 4.0), in which industrial production is entering a turning point - after the era of steam, electricity and computers, comes the period of digitization. The main recipients of the changes brought by the concept of Intelligent Industry are Slovak industrial companies, which will increase their competitiveness because of the possibility of more efficient production and sale of products. The changes also bring benefits to small SMEs, especially suppliers of equipment, technologies and services, because of the interconnected industrial production. This will also enable the emergence of new business models.
Industry 4.0 is changing the current form of Slovak industry. The priority of the industry becomes:

- introduction of automation and digital production,

- digitization of control systems,

- usage of communication networks to ensure interoperability and flexibility of business processes.

The intelligent industry characterizes therefore a constant increase in innovation and is a driving force in the development of science and applied research in Slovakia and the development of scientific workplaces that produce knowledge for further development and use basic research to solve the innovative requirements of industrial practice. The vision of a smart industry also represents the efficient usage of scarce resources and raw materials.

c. In the near future, human work will be transformed into creative activity, while physically demanding routine work will be delegated to machines and systems. Support for innovative solutions in Slovak cities.

The document "Support for Innovative Solutions in Slovak Cities" is one of the activities, which can create a basis for the support of Smart City projects in the Slovak Republic. This document describes the key aspects of the Smart City topic with emphasis on their implementation in practice. At the same time, however, it brings a practical tool for companies and cities in the form of new support mechanisms and an overview of already implemented examples at home and abroad.

Smart City solutions should also generate economic benefits in the long-term view, i.e. savings, either on the side of active income or directly at the level of self-government, respectively at the level of individual actors. Modern cities are attractive for innovative companies, and with the arrival of these companies grows the innovative potential of the whole city.

\section{Buildings}

Government/local government

digital public administration, participatory management,

e-services.

Energy and Environment

Education

$$
\begin{aligned}
& \text { urban education platforms, } \\
& \text { digital formats for learning, } \\
& \text { digital skills. }
\end{aligned}
$$

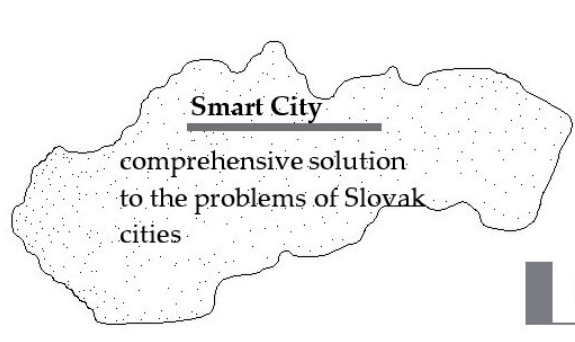

Health

telemedicine

o integrated health information systems,

- extended care for the disadvantaged.
○ intelligent energy management,

o intelligent water management,

$\circ$ intelligent waste management.

\section{Mobility}

intelligent traffic management systems, intelligent public transport services, intelligent urban logistics.

Fig. 3. Smart City components. 
On the other hand, there is the issue of local government resources to support "smart" activities and the issue of political sustainability of time and financially costly solutions.

Building smart cities requires a comprehensive approach and the participation of a wide range of stakeholders. Given the specifics of each city, there is no universal approach to becoming "Smart." However, it is true that a smart city uses modern technology. Smart City components are shown in Fig. 3.

d. Concept for support of start-ups and development of start-up ecosystem.

The concept for support of start-ups and development of start-up ecosystem is embedded in a broader concept of gradual pro-growth actions to support the Slovak economy and the innovation policy of the Slovak Republic. The actions divide into the following strategic goals:

- Creation of suitable conditions for business, i.e. creation of a regulatory environment without unnecessary barriers for origin and operation of start-ups in the market.

- Creation and provision of support services to strengthen the start-up ecosystem, i.e. creation of infrastructure and services to support people interested in business, start-up teams and established start-ups.

- Financing especially the so-called "Death Valley" phase of business initiatives, because in this phase most of start-ups fail.

D. Support tools

a. Innovation Fund.

Innovation Fund n. f. is an independent non-profit, non-state legal entity operating in the territory of the Slovak Republic.

The purpose of this fund is to support the sustainable development of spiritual values in the field of science, $\mathrm{R} \& \mathrm{D}$ and thus accelerate innovative development in the Slovak Republic. The fund pays special attention to the support of development and conceptual studies that determine the main areas of usage of the results of scientific and R \& D solutions. The Innovation Fund is a non-investment fund that works on the principle of repayable financing.

b. Innovation vouchers.

Innovation vouchers work with the aim of initiation and intensification of direct cooperation between entrepreneurs and selected R \& D institutes, in the form of a non-repayable grant.

Innovation vouchers are financed from the state budget and they have to support the development of innovative activities in companies. Entrepreneurs can apply for support the activities that are focused on innovation of their own products, services or technologies.

c. Clusters.

The subject of the Scheme for the Support of Industrial Cluster Organizations is the provision of de minimis aid in the form of a support from the state budget for financing projects aimed at supporting the development of interest groups of legal entities.

The assistance aims at intensification of information transfer, expert activities, presentations of industrial cluster organizations and their involvement into international projects and networks.

d. International cooperation in industrial R \& D.

The subject of this scheme is the provision of state aid for solving projects of industrial research and experimental development directed to innovations in the form of a support from the state budget of the Slovak Republic aimed at support of the solutions of joint projects of international cooperation in industrial research and experimental development.

The Slovak Republic has a specific international cooperation with the Republic of Israel.

The aim of the support is to intensify cooperation between Slovak and Israeli companies in solving joint projects in the field of industrial research and experimental development.

e. Innovative solutions in cities.

The aim of this scheme is to support innovative SMEs in putting innovative solutions into practice, specifically in building smart cities, which will lead to improve their access to modern technologies and processes and finally to their more efficient functioning and increasing og their potential for urban development and growth.

C. Events and competitions

As part of the support, various forms of events and competitions are also organized. These are in particular:

a. The young creator.

b. Innovative act of the year.

c. Cosmo.

d. Conference-CERN-Slovakia: industry and knowledge transfer.

e. SK PRES.

5. The Ministry of Education, Science, Research and Sport of the Slovak Republic

A. The Operational Program Research and Innovation

The Operational Program Research and Innovation (OP R\&D) is based on the priorities of the Europe 2020 strategy, as well as on the main recommendations of the Small Business Act and the Action Plan for Entrepreneurship 2020.

OP R\&D is a key implementation tool of the strategy "Knowledge for Prosperity - Research and Innovation Strategy for Intelligent Specialization of the Slovak Republic" (RIS3 SK).

The Operational Program Research and Innovation is a programming document for providing support from the European Structural and Investment Funds in the 2014-2020 programming period. It is oriented on the creation of a stable, innovation-friendly environment for all relevant subjects. It is also aimed at support of increased efficiency and effectiveness of the R\&D and innovation system as a key pillar for increasing competitiveness, sustainable economic growth and employment. 
The total allocation of the OP R\&D is 2266776 537 EUR, where more than 3/4 of all funds are intended to strengthen research, technological development and innovation, and the remaining $1 / 4$ is allocated to support the increase of competitiveness of SMEs.

The structure of the OP R\&D at the level of thematic goals and priority axes is shown in Fig. 4.

OP R\&D is implemented through four thematic priority axes and one priority axis focused on technical assistance and contributes to the fulfilment of thematic goal 1 and thematic goal 3 (Fig. 4).

B. Information support of research and development and technology transfer

a. The Centre of Scientific and Technical Information.

The Centre of Scientific and Technical Information of the Slovak Republic is a national information centre and a specialized scientific public library of the Slovak Republic focused on technical fields and selected areas of natural, economic and human sciences.

It is the national information centre for science, technology, innovation and education and the scientific library of the Slovak Republic. It coordinates the activities and ensures the operation of interdisciplinary $R \& D$ centres and national infrastructures for $R \& D$, innovation and education.

b. The Central information portal for research, development and innovation.

The Central Information Portal for Research, Development and Innovation represents one of the basic information, management and control tools of the state scientific and technical policy.

The portal is intended for both professional and lay users from the Slovak environment, and at the same time the information provided within it also serves foreign users.

6. The Ministry of Investments, Regional Development and Informatization of the Slovak Republic

This element does not have such specific programs, tools, strategies, respectively policies, as the previous two institutions (i.e. The Ministry of Economy of the Slovak Republic and The Ministry of Education, Science, Research and Sport of the Slovak Republic).

This office supervises some of the announced schemes, which belong under the previous two ministries.

In principle, it provides some double protection when drawing funds, because investments belong under this office.

In addition, other organizations focus also on innovation in the Slovak Republic:

1. The Slovak Innovation and Energy Agency

The Slovak Innovation and Energy Agency (SIEA) performs the role of the technology agency. This agency focuses on several key areas:

a. Domains of intelligent specialization - they correspond with the Strategy of research and innovation for intelligent specialization of the Slovak Republic (RIS3).

b. Project "Inovujme.sk" - project aims to raise awareness of the importance of innovation among Slovak entrepreneurs, but also at high schools and universities in all regions.

c. Project "Support of the Creative Industry Development in Slovak republic" - project aims at the development of innovation processes through cooperation of SMEs with actors in the creative industry.

d. International Cooperation Program "Innovation for Slovakia and Israel" - it corresponds with the International Cooperation in Industrial Research and Development with the Republic of Israel mentioned above.

e. Innovation vouchers - they correspond to the support tools that were mentioned above.

f. Grants for industrial clusters - they correspond with the support instruments that were mentioned above.

g. Innovative act of the year - it corresponds with the event that was mentioned above.

h. International projects - there are several projects.

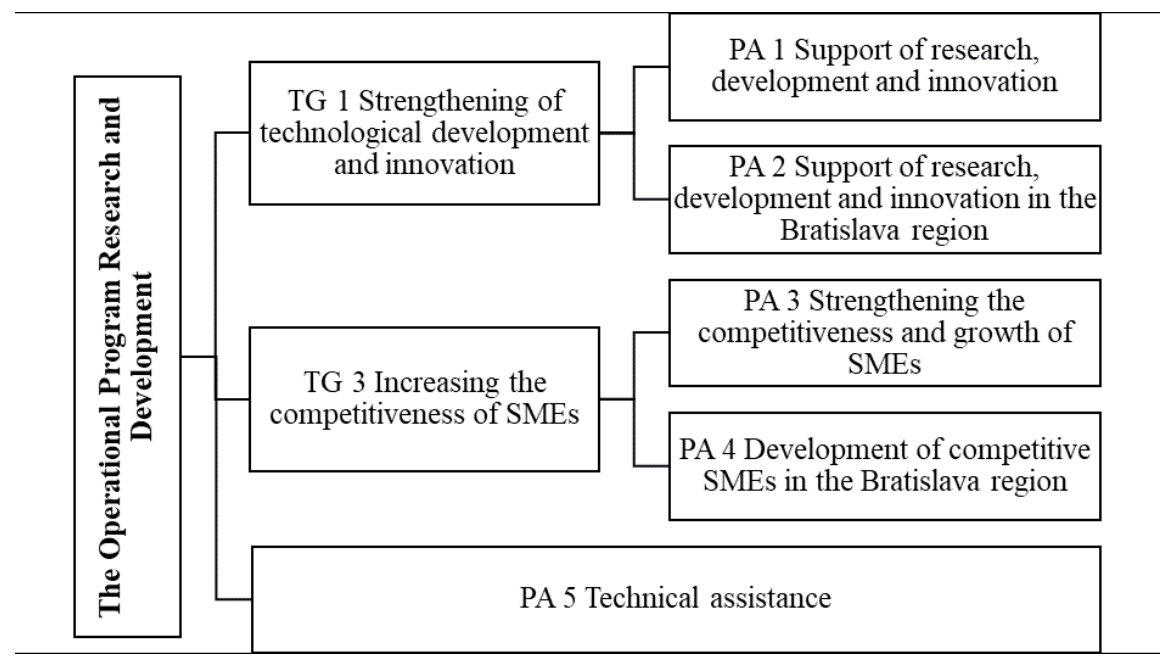

Fig. 4. Structure of OP R\&D at the level of thematic goals (TG) and priority axes (PA). 
Table 2. Network of Business and Innovation Centres and Regional Consulting and Information Centres in the Slovak Republic.

\begin{tabular}{|c|c|c|}
\hline Type of Centre & Localization & Description \\
\hline $\begin{array}{l}\text { Business and } \\
\text { Innovation } \\
\text { Centres }\end{array}$ & $\begin{array}{c}\text { Bratislava, } \\
\text { Kosice, } \\
\text { Banska Bystrica, } \\
\text { Prievidza, } \\
\text { Spisska Nova Ves. }\end{array}$ & $\begin{array}{l}\text { Business and Innovation Centres are institutions for the support of innovation } \\
\text { and entrepreneurship and are the result of the efforts of the European Com- } \\
\text { mission, the private and public sectors to support economic development and } \\
\text { innovation potential in the European region. } \\
\text { Business and Innovation Centres offer services related to the innovation process } \\
\text { in companies. These are services such as consulting (e.g. obtaining financial } \\
\text { resources, participation in EU programs, etc.), financing and financial consult- } \\
\text { ing, technology transfer, establishing cooperation with universities and research } \\
\text { workplaces, respectively business incubation. }\end{array}$ \\
\hline $\begin{array}{l}\text { Regional } \\
\text { Consulting and } \\
\text { Information } \\
\text { Centres }\end{array}$ & $\begin{array}{c}\text { Bratislava, Dunajska Streda, } \\
\text { Komarno, } \\
\text { Kosice, } \\
\text { Lucenec, } \\
\text { Poprad, } \\
\text { Povazska Bystrica, } \\
\text { Presov, } \\
\text { Trebisov, } \\
\text { Trencín, } \\
\text { Roznava - active } \\
\text { Zvolen, } \\
\text { Martin, } \\
\text { Nitra - currently inactive }\end{array}$ & $\begin{array}{l}\text { Regional Consulting and Information Centres are non-profit institutions estab- } \\
\text { lished based on the private sector as independent regional associations of legal } \\
\text { entities. They are financially supported by Slovak as well as by foreign funds } \\
\text { focused on the support of SMEs. They provide free consulting, information and } \\
\text { educational services. The mission of the centres is oriented on the following } \\
\text { areas: } \\
\text { 1. Support for SMEs (consulting for companies and start-ups). } \\
\text { 2. Processing and implementation of projects (business plans). } \\
\text { 3. Rental of premises with a discount for start-up entrepreneurs (office and pro- } \\
\text { duction premises, storage premises, other areas). } \\
\text { 4. Provision of services (internet, copying works, secretarial works, etc.). }\end{array}$ \\
\hline
\end{tabular}

2. Business and innovation centres and Regional Consulting and Information Centres

The barrier of the effective usage of new ideas in business is often insufficient innovation management. Innovation management fails in the process of selection of the right ideas, organizational structure, employee motivation, patent protection, usage of licenses, marketing of innovations, or securing funds for their development. For this reason, the European Commission has set up innovation management support for SMEs through the Enterprise Europe Network, to ensure their growth and the development of competitiveness based on innovation.

In the Slovak Republic, it is implemented through a network of Business and Innovation Centres (BIC) and Regional Consulting and Information Centres (Table 2).

\section{Results and Discussion}

Eco-innovation in Slovak republic will be complied based on own research and own information and also according to statistics from Slovak Business Agency that would be analyzed.

\section{Eco-Innovation as the Necessary Goal for Every Economy in the Intentions of Sustainable Development}

The concept of eco-innovation is relatively new term and it was first used in the late 1990s. It has been introduced in the context of ensuring sustainable development (SD), while from the economic point of view are preferred solutions aimed at ensuring economic growth on the one hand and environmental sustainability and stability on the other hand. In this case, it is the so-called sustainable growth of the global economy, where the growth of one quantity is not realized at the expense of the other quantity, but in symbiosis with it, respectively with regard to it [18-20].

There are many definitions of eco-innovation and therefore there is no uniform basic description of these activities, although in principle it is valid to produce more from a smaller number of inputs - raw materials, energy with less waste production and emissions. According to the European Commission (2006), eco-innovation is any innovation aimed at making significant and visible progress towards the goal of sustainable development, by reducing environmental impacts or achieving a more efficient and responsible usage of natural resources, including energy. In 2010, the OECD for the first time defines eco-innovation as the implementation of new or significantly improved products (goods or services), processes, marketing methods, organizational structures or institutional arrangements that purposely or as a side effect lead to improving the environment. Eco-innovations are divided by various authors and institutions into subcategories such as - technical, organizational, social, institutional, or technological, product, green systemic, or complementary.

Eco-innovation is important for the economy, such as saving materials and energy, introducing new products, services, business models and by opening the new markets [21]. From an environmental point of view, they are important for the sustainable management of natural resources, in the fight against climate change and the improvement of biodiversity or ecosystems. 


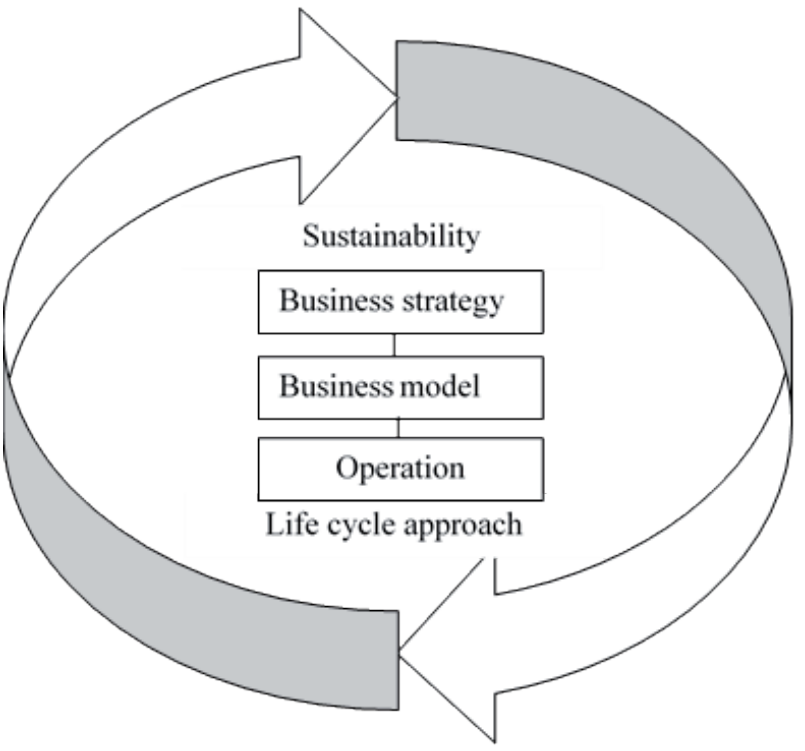

Fig. 5. Conceptual model of eco-innovation [24].

From a social point of view, they are important for the improvement of the quality of life and creation of sustainable jobs $[22,23]$. They represent a source of justice and material security for politics. The conceptual model of eco-innovation is in Fig. 5 [24].

At the same time, the necessity for innovation results from the changes in the world and the world economy, which in turn require these innovations $[25,26]$. Table 3 shows the factors, pressures and changes affecting companies that consider eco-innovation [27, 28].

Several implemented studies in several countries of the world (including the territory of the EU) point to the fact that in general approximately $55-60 \%$ of implemented innovations bring the environmental benefits, respectively benefits conducive to sustainability and sustainable growth. From the above-mentioned facts, it is clear that eco-innovation is already an integral part of innovation activities in companies [29]. The importance of eco-innovation is in Table 4 [30-32].
There is an increased necessity to find alternative approaches that could help by solving challenges of sustainable business development and to offer opportunities for growth, cost reduction and competitive advantage [33, 34].

\section{Eco-Innovation in the Slovak Republic}

In 2019, almost $31 \%$ of companies in Slovakia have already implemented various measures to reduce their negative impact on the environment in the past period, while another $46 \%$ of entrepreneurs are now implementing such measures. On the other hand, $18 \%$ stated that they do not introduce eco-innovation now and they do not plan to do it in the near future. This follows from a survey of hundreds of companies in Slovakia, which was carried out by the Datank agency.

More than $42 \%$ of companies are motivated to make eco-innovation by social responsibility, and almost $33 \%$ of respondents simply consider it as right and natural. Round $16 \%$ of companies have the introduction of ecological processes and innovations ordered by legislation.

Many companies in Slovak republic stated that they do not implement environmental measures, because of the fact that they do not have a chance to affect the environment as a part of their business activities. The highest representation among these companies was in the field of wholesale, retail, repairs and maintenance, as well as administration $[35,36]$.

When we look at the regions, the result is that most companies supporting eco-innovation are in the Trnava region, where $85 \%$ of the addressed companies have already implemented or start to introduce measures to protect the environment. On the other hand, most companies with exactly opposite plans are in the Nitra region, concretely $25 \%$.

Regardless of the company size, the most common measure is waste recycling, which has been actively adopted by more than $36 \%$ and $17 \%$ of entrepreneurs reach for energy-saving electrical appliances. About $15 \%$ of companies use new ecological materials or

Table 3. Global changes taking into account sustainability and their potential impact on business [27, 28].

\begin{tabular}{|c|c|c|}
\hline Risk factors & Regulator pressures & Market changes \\
\hline Lack of resources & $\begin{array}{c}\text { Significant increase in regulations and } \\
\text { standards for industry }\end{array}$ & $\begin{array}{c}\text { Growing customer demand for sustainable } \\
\text { products and services. }\end{array}$ \\
\hline Price volatility of commodities & & New markets for innovative solutions \\
\cline { 1 - 1 } The increased level of natural disasters & $\begin{array}{c}\text { Life-cycle approaches are now } \\
\text { included in the regulations }\end{array}$ & $\begin{array}{c}\text { Growing pressure on suppliers to meet strict } \\
\text { sustainability criteria. }\end{array}$ \\
$\begin{array}{c}\text { Environmental degradation and biodiversity } \\
\text { loss }\end{array}$ & $\begin{array}{c}\text { Sustainability factors in investor decision } \\
\text { making. }\end{array}$ \\
\hline \multirow{2}{*}{$\begin{array}{c}\text { Health and social impacts of operations } \\
\text { (e.g. Covid-19 pandemic) }\end{array}$} & $\begin{array}{c}\text { Transparency in the area of business } \\
\text { sustainability is increasingly } \\
\text { mandatory }\end{array}$ & $\begin{array}{c}\text { Growing partnerships to maximize the } \\
\text { impact of sustainability and shared profits. }\end{array}$ \\
\hline
\end{tabular}


Table 4. Importance of eco-innovation [30-32].

\begin{tabular}{|c|c|}
\hline Affected area & Description of benefits \\
\hline Economy & $\begin{array}{l}\cdot \text { Saving materials and energy costs, } \\
\cdot \text { New products and services, } \\
\cdot \text { New business models, } \\
\text { • New markets and business opportunities. }\end{array}$ \\
\hline Environment & $\begin{array}{l}\text { - Sustainable management of natural resources, } \\
\text { • Combating climate change, } \\
\text { - Improving biodiversity and ecosystems. }\end{array}$ \\
\hline Society & $\begin{array}{l}\text { - Improving the quality of life, } \\
\text { - Creation of new and sustainable jobs. }\end{array}$ \\
\hline Policy & $\begin{array}{l}\text { - Material security, } \\
\text { - Source of justice. }\end{array}$ \\
\hline
\end{tabular}

ecological packaging materials in production and $8 \%$ of entrepreneurs work with ecological technologies.

A "greener" approach also means higher investment in some sectors. The majority of companies $(70 \%)$ in the survey stated that additional costs do not reflect to the final prices. Of course, in this case, the decisive factor is in which industry the company operates and for which type of measure it has decided. On average, 7 out of 100 entrepreneurs contacted include these costs in the value of a product or service, and another $25 \%$ of companies partially reflect the costs of eco-innovation in the price of products and services,

Finance and the necessary investments are also the main reasons that entrepreneurs consider in a "greener" way. Almost $33 \%$ of companies do not want to be ecological precisely because of the financial demands of investments in environmental protection. Another $14 \%$ of entrepreneurs are bound by legislation, $6 \%$ of companies complain about the lack of experts, $5 \%$ of entrepreneurs do not have demand from customers and $17 \%$ of companies have business in a field that does not allow environmental measures. Skepticism is the main reason for $2 \%$ of respondents.

Despite some of the above-mentioned negative facts, in Slovak Republic we can categorise many successful eco projects as the eco-innovation. We can mention the 10 most successful eco projects:

1. Bez odpadu - we are not aware of the fact, how much waste we throw away every day. Most of it consists of food packaging that we have consumed. The Slovak online store of sprinkled food (Bezodpadu. sk - No waste) tries to prevent this. In this store, you will not come across any unnecessary packaging. Healthy local foods such as dried legumes, nuts, cereals, dried fruits and more this store will deliver to you in a paper or cloth bag, glass cup or bottle or packaging that you bring yourself (Fig. 6).

2. Ridelo - the world's first portable bicycle charger for phones in the world was made by two Slovak high school students, Filip and Adrián, who wanted to bring something revolutionary to the world that would benefit the environment. It is a truly unique way to charge your phone. The technology works on the principle of magnets, is almost noiseless and allows you to charge the device by pedaling. The Ridelo charger (Fig. 7) is waterproof, includes light and operates on pure green energy.

3. Ecoheart - Ecoheart brushes (Fig. 8) are friendly to your teeth and nature. The young Slovak and vegetarian Roman Kovacs is the leader of this project. Each brush has a hand-worked bamboo body and is designed in such way that it fits exactly in your hand. Thick bristles are made of quality nylon fibre and brushes are a long-term sustainable product.

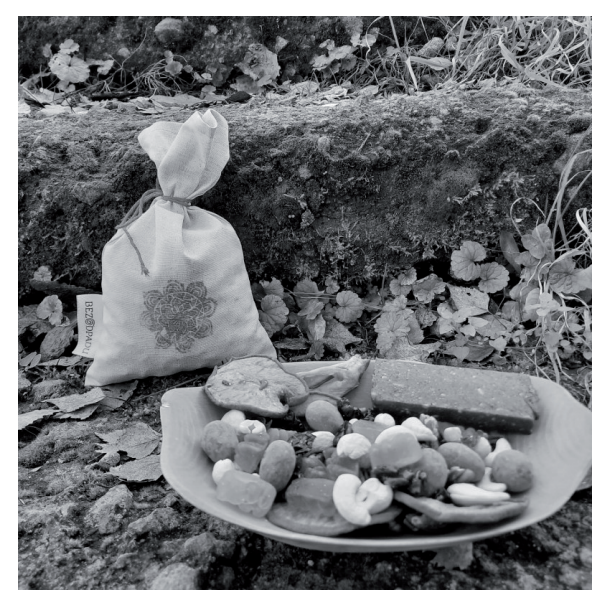

Fig. 6. Packages in the store Bez odpadu.

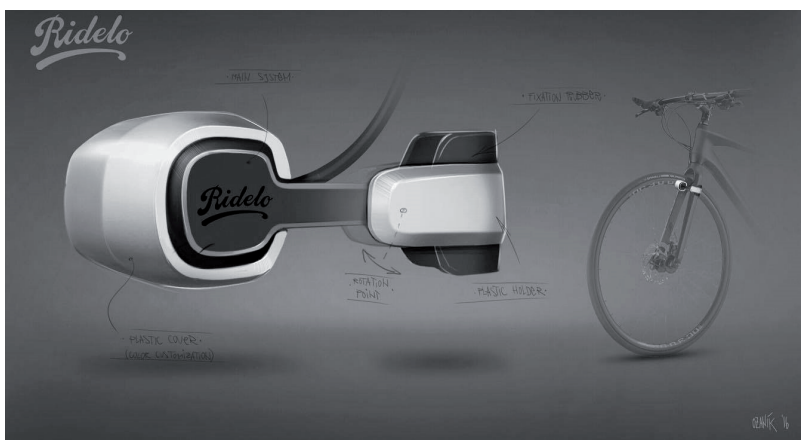

Fig. 7. Ridelo charger. 

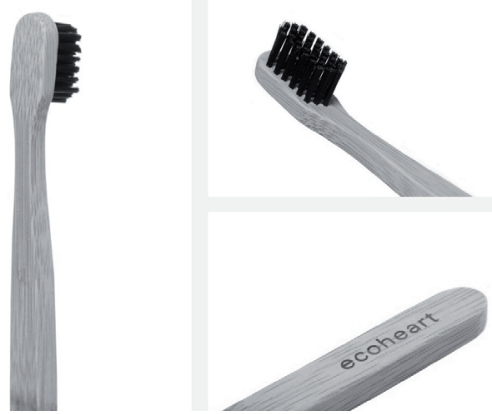

Fig. 8. Ecoheart brushes.

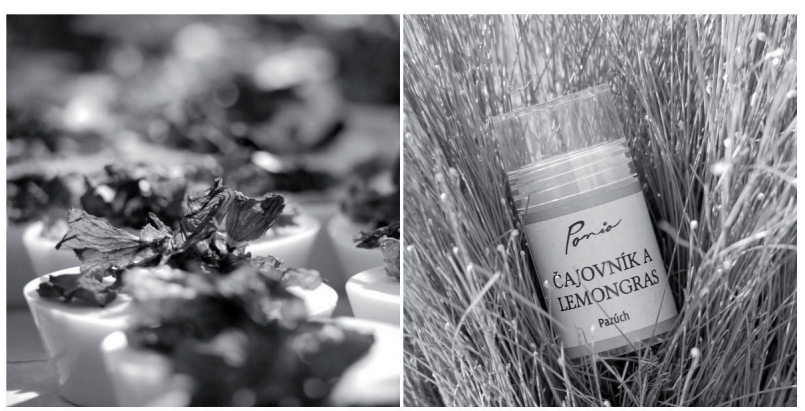

Fig. 9. Ponio gift sets.

If you will buy this product, you will contribute to non-profit projects and thus help make our environment more beautiful and better.

4. Ponio - it is the equivalent of the world-famous Lush cosmetics. Ponio produces natural products without any chemical additives. It is zero waste cosmetics. In the brand's portfolio, you can find natural soaps, shampoos, conditioners, massage cubes and deodorants. All products are handmade and cold using with vegetable and essential oils, so they are rich in nutrients. Ponio gift sets is in Fig. 9.

5. Dedoles - this brand cares not only about quality, but also about the future of the planet. Dedoles tries to bring a piece of nature into your wardrobe,

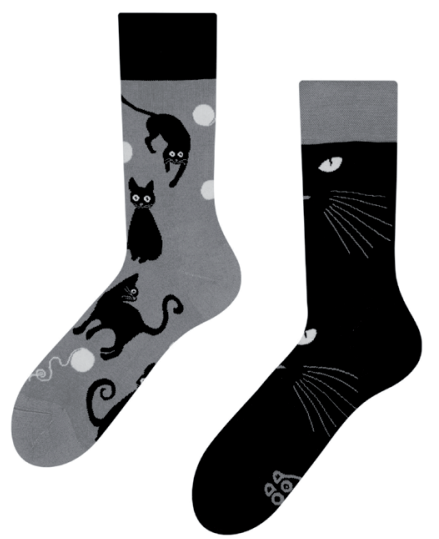

Fig. 10. Dedoles socks.

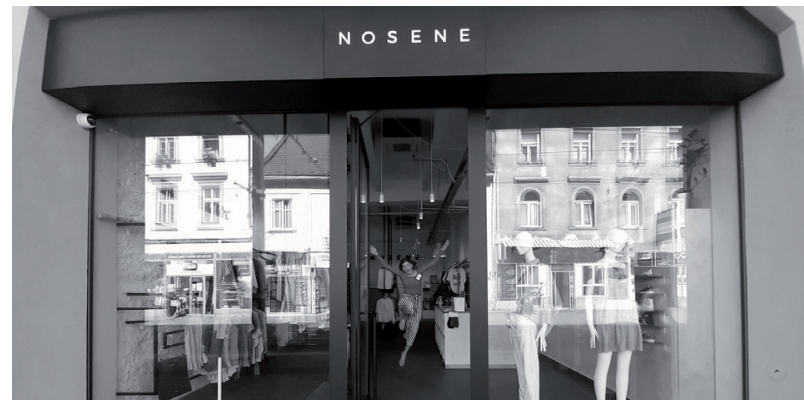

Fig. 11. Second-hand Nosene.

in addition, it will refresh it with creative animal motives. It is not only an online store, but also a community of nature lovers who support handmade and environmental protection. Each socks (Fig. 10) are unique and is hand-painted with organic colours. Special technology keeps the print for a long time. The brand is already known in the Czech Republic, Austria, Hungary, Germany and Romania.

6. Nosene - clothing recycling is an increasingly widespread topic today and is more than necessary for the quantity of textile production. Secondhand Nosene (Fig. 11) is the leader in slow fashion and sustainable fashion in Slovakia. More and more Slovak people are interested in second-hand clothes, and it is here that they will find quality at an affordable price and leave this store with the feeling that they have enriched their wardrobe and lighten the environment.

7. Ecoterra - it is the Slovak drugstore with the Italian drugstore (Fig. 12). This drugstore is ecologic and without packaging. The brand try to reduce the consumption of plastics and another purpose of this brand is recycling. Customer can bring own bottle and add products into it. The offer includes cleaning and washing products, soaps and shampoos. The advantage of this store is that you can buy the amount you can consume and you do not pay extra for packaging, labels and advertising.

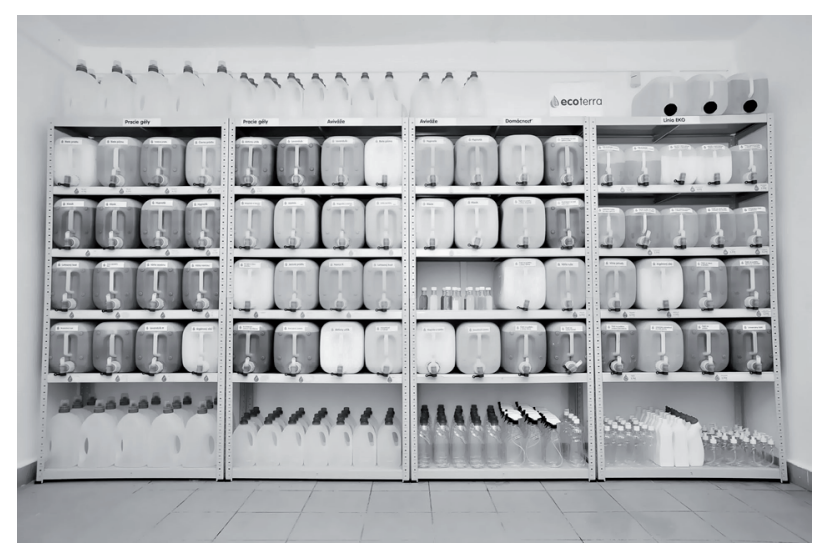

Fig. 12. Ecoterra store. 


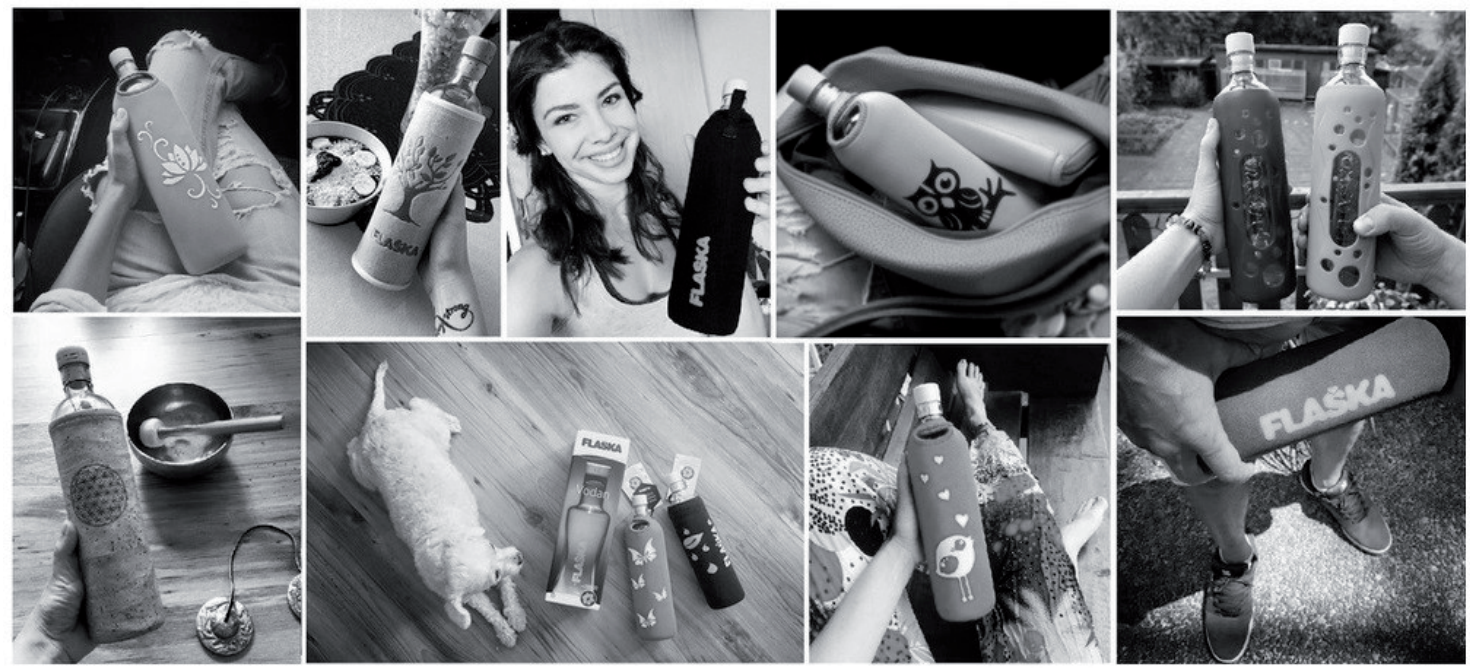

Fig. 13. Bottle store.

8. Flaska - idea of this store (Flaska - Bottle) is not to buy bottled water store, but this store motivate you to be ecological and stylish at the same time. Bottle (Fig. 13) is made of durable vibrating tuned glass and thus takes care of our health and environment. Because the glass is fragile, the bottle is covered with neoprene, silicone, cotton or cork, which are all ecological materials. You can customize the bottle to your style by various colours and motives, or the possibility of printing a name, greeting card or quote.

9. Pure Junk - Slovak company Pure Junk produces recycled designer furniture and accessories (Fig. 14). It also dedicates to designing interiors and solutions for companies. The brand's vision is to reduce the amount of waste through cooperation with waste collections and construction companies that have a redundancy of such waste.

10. White Bikes - is the bike sharing project in Bratislava. The goal of White Bikes (Fig. 15) is very simple - to support cycle transport and thus get rid of at least a few cars.

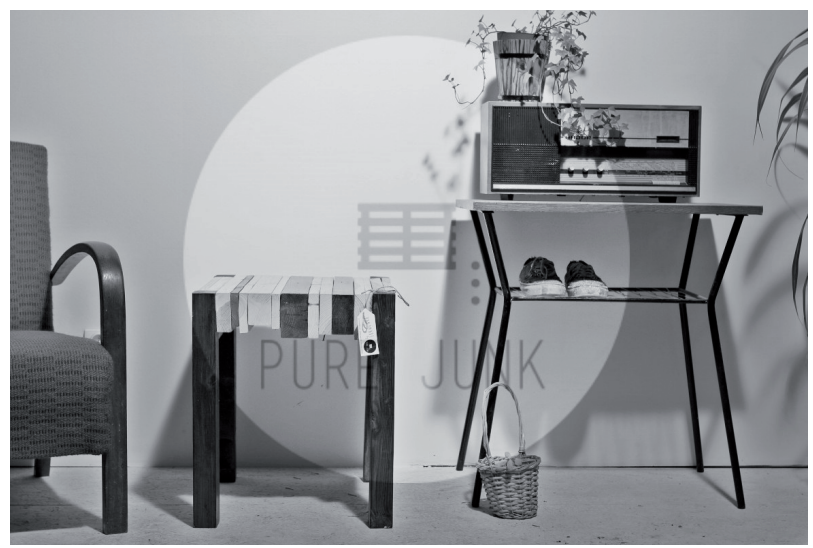

Fig. 14. Examples of Pure Junk production.
As the result of above mentioned facts, it is clear that Eco-innovation in Slovak republic have a big potential to raise, so it will be good to evaluate it through EcoInnovation Index, which is one of the most important toll for this purpose.

Eco-Innovation Index illustrate eco-innovation performance across the EU Member States. It aims at capturing the different aspects of eco-innovation by applying 16 indicators grouped into five dimensions:

1. eco-innovation inputs,

2. eco-innovation activities,

3. eco-innovation outputs,

4. resource efficiency,

5. socio-economic outcomes.

The importance of Eco-Innovation Index is that it shows how well EU Member States perform in different dimensions of eco-innovation compared to the EU.

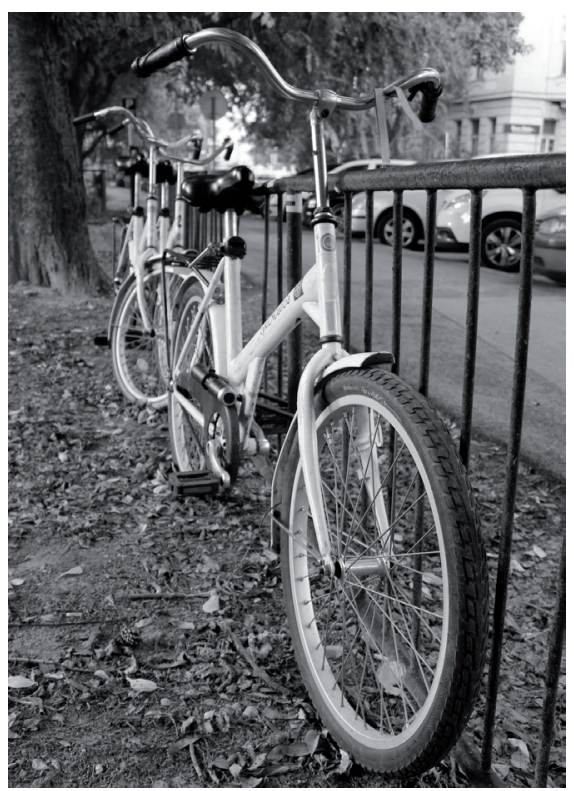

Fig. 15. White Bikes. 


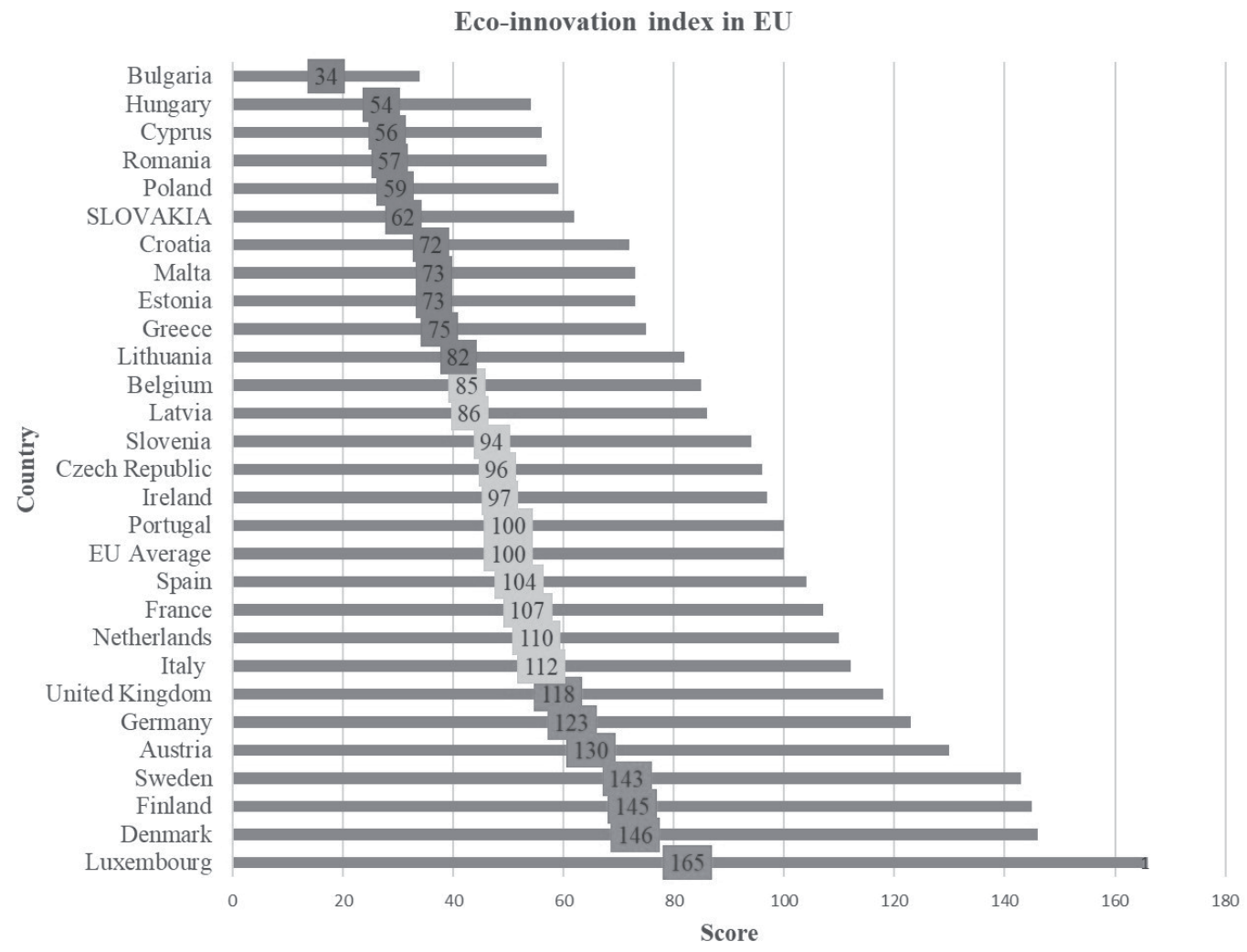

Fig. 16. Eco-innovation index in EU [37].

Eco-Innovation index in EU Member States including Slovak republic in year 2018, which is the last known year, is in Fig. 16 [37].

From Fig. 16 it is clear that eco-innovation in Slovak republic are below the EU average and the position of Slovak republic (23 $3^{\text {rd }}$ place) is bad, because behind Slovak republic are only Romania, Malta, Poland, Bulgaria and Cyprus and there is a big opportunity to improve this position in the near future.

Eco-Innovation index is on the level 68 and Slovak republic is in the group of countries that catching up with Eco-innovation index.

Compared to year 2017, Slovak republic decreased in Eco-Innovation index, because in 2017 the EcoInnovation index was on the level 75 in 2017 and reached $21^{\text {st }}$ place. The Slovakia's performance has improved compared to 2010 when the overall score of Eco-Innovation index was only 43 (it was ranked on $23^{\text {rd }}$ place), while in 2015, Eco-Innovation index has increased to 61 .

\section{Conclusions}

The pressure to strengthen the innovation performance of national economies is constantly increasing [38-39]. It also grows the importance of analyzes and comparisons of innovation performance, whether at the national or company level. Slovak Republic has a demonstrable innovation potential within the EU, but its growth still needs to be stimulated and supported. Compared to other economically stronger countries, Slovak republic has limited resources, which are also used for a number of fragmented goals. For the development of the Slovak Republic innovation potential and thus the subsequent expected increase in innovation performance, it is necessary to use domestic innovation capacity more intensive.

The success and effectiveness of eco-innovation of goods and services requires a constant reduction of their impact on the environment and health at all stages of their life cycle with their wider application in the market. Bringing a product closer to the customer and increasing its attractiveness and competitiveness also requires the promotion of awareness of environmentally friendly products, not only from the EU level, but also from the level of legislation of a particular Member State. Incomplete information, resp. Problems with funding and bad communication between R \& D and companies is one of the reasons why the company's management does not focus on the environmental dimension of sustainability, but only on taking measures to reduce the harmful effects of production on the environment. The lack of eco-innovation in Slovak companies clearly indicates the necessity to create a methodology for the implementation and management of eco-innovation in Slovakia.

The most significant factor and driving force of the rapid development of companies and the achievement of a better competitive position in the market have recently become not only innovation, but also rapid 
growth in eco-innovation and the implementation of eco-innovation processes [40]. These world trends significantly contribute not only to the creation of the country's innovation system and the sustainable development of the Slovak economy, which is important for the future generations, but also represent the value of economic strength and are a fundamental determinant of business development [41].

\section{Acknowledgements}

This research was funded by KEGA, grant number 002TUKE-4/2020" Implementation of intelligent technology and advanced technologies to support transformation processes and future product design and KEGA 032EU-4/2020 Implementation and Educational Model of Intelligent Business Logistics.

\section{Conflict of Interest}

The authors declare no conflict of interest.

\section{References}

1. GOFFIN K., MITCHELL R. Innovation management: effective strategy and implementation, $3^{\text {rd }}$ Ed.; Red Globe press: NY, USA, 440, 2016.

2. BIRKINSHAW J., HAMEL G., MOL M. Management Innovation. Academy of management Review, 33, 4, 2008.

3. BOER H., DURING W.E. Innovation, what innovation? A comparison between product, process and organizational innovation. International Journal of Technology Management, 22, 1, 2001.

4. COAD A., SEGARRA A., TERUEL M. Innovation and firm growth: Does firm age play a role? Research Policy, 45, 2, 2016.

5. FLØYSAND A., JAKOBSEN S.-E. The complexity of innovation: A relational turn. Progress in Human Geography, 35, 3, 2011.

6. GHERGHINA Ș.C., BOTEZATU M.A., HOSSZU A., SIMIONESCU L.N. Small and Medium-Sized Enterprises (SMEs): The Engine of Economic Growth through Investments and Innovation. Sustainability, 12, 1, 2020.

7. KNIGHT A., CAVUSGIL T. Innovation, Organizational Capabilities, and the Born-Global Firm. Journal of international business studies, 35, 2, 2004.

8. PISAR P. Regional innovation in the European Union and Slovakia, $1^{\text {st }}$ Ed.; Belianum: Banska Bystrica, Slovakia, 250, 2019

9. WIGNARAJA G. Competitiveness Strategy in Developing Countries. A Manual for Policy Analysis, $1^{\text {st }}$ Ed.; Routledge: London, UK, 306, 2003.

10. LI M., YU T. Does R\&D internationalization promote enterprise innovation: An empirical research based on China's information technology enterprises. Management World, 11, 2016.

11. HSU C.W., LIEN Y.-C., CHEN H. R\&D internationalization and innovation performance. International Business Review, 24, 2, 2015.
12. HE J., CHEN H., TSAI F.-S. Strategy Orientation, Innovation Capacity Endowment, and International R\&D Intensity of Listed Companies in China. Sustainability, 12, $1,2020$.

13. PIERONI M.P.P., MCALOONE T.C., PIGOSSO D.C.A. Business model innovation for circular economy and sustainability: A review of approaches. Journal of Cleaner Production, 215, 2019.

14. SAKAL P. Sustainable corporate social responsibility II. Strategy for sustainable development, $2^{\text {nd }}$ Ed.; AlumniPress: Trnava, Slovakia, 349, 2013.

15. KERIN M., PHAM D.T. A review of emerging industry 4.0 technologies in remanufacturing. Journal of Cleaner Production, 237, 2019.

16. OBI J., IBIDUNNI A.S., TOLULOPE A., OLOKUNDUN M.A., AMAIHIAN A.B., BORISHADE T.T., FRED P. Contribution of small and medium enterprises to economic development: Evidence from a transiting economy. Data in Brief, 18, 2018.

17. EXPOSITO A., SANCHIS-LLOPIS J. A. The relationship between types of innovation and SMEs'performance: A multi-dimensional empirical assessment. Eurasian Business Review, 9, 2, 2019.

18. CARRILLO-HERMOSILLA J., DEL GONZÁLEZ P.R., KÖNNÖLÄ T. Eco-innovation in practice, $1^{\text {st }}$ Ed.; Palgrave Macmillan: London, UK, pp. 125, 2009.

19. HOJNIK J., RUZZIER M. What drives eco-innovation? A review of an emerging literature. Environmental Innovation and Societal Transitions, 19, 2016.

20. VARADARAJAN R. Innovating for sustainability: A framework for sustainable innovations and a model of sustainable innovations orientation. Journal of the Academy of Marketing Science, 45, 1, 2017.

21. KALMYKOVA Y., SADAGOPAN M., ROSADO L. Circular economy - From review of theories and practices to development of implementation tools. Resources, conservation and recycling, 135, 2018.

22. ADAMS R., JEANRENAUD S., BESSANT J., DENYER D., OVERY P. Sustainability-oriented innovation: A systematic review. International Journal of Management Reviews, 18, 2, 2016.

23. AARSTAD J., JAKOBSEN S.-E. Norwegian Firms' Green and New Industry Strategies: A Dual Challenge. Sustainability, 12, 1, 2020.

24. KABDI K., BOSAK M., MAJERNIK M., MIHOK J. Technics scrap recycling technologies, $1^{\text {st }}$ Ed.; Kokshetau University: Kokshetau, Kazakhstan, 342, 2009.

25. ANTIKAINEN M., VALKOKARI K. A framework for sustainable circular business model innovation. Technology Innovation Management Review, 6, 7, 2016.

26. KONIETZKO, J., BOCKEN, N., HULTINK, E.J. A Tool to Analyze, Ideate and Develop Circular Innovation Ecosystems. Sustainability, 12, 1, 2020.

27. BOCKEN, N.M.P., BOONS, F., BALDASSARRE, B. Sustainable business model experimentation by understanding ecologies of business models. Journal of Cleaner Production, 208, 2019.

28. KABDI K., MAJERNIK M., MIHOK J., BOSAK M. The aspects of the environmental management, $1^{\text {st }}$ Ed.; Kokshetau University: Kokshetau, Kazakhstan, 287, 2008.

29. STUBBS W., COCKLIN C. Conceptualizing a "Sustainability Business Model" Organization \& Environment, 21, 2, 2008. 
30. KABDI K., MAJERNIK M., BOSAK M., MIHOK, J. Technics and environment and vice versa, $1^{\text {st }}$ Ed.; Kokshetau University: Kokshetau, Kazakhstan, 365, 2010.

31. PIGOSSO D.C., ZANETTE E.T., GUELERE FILHO,A., OMETTO A.R., ROZENFELD H. Ecodesign methods focused on remanufacturing. Journal of Cleaner Production, 18, 1, 2010.

32. ROSSI M., GERMANI M., ZAMAGNI A. Review of ecodesign methods and tools. Barriers and strategies for an effective implementation in industrial companies. Journal of Cleaner Production, 129, 2016.

33. LEWANDOWSKI M. Designing the business models for circular economy-towards the conceptual framework. Sustainability, 8, 1, 2016.

34. ZHANG G.Y., GUAN R., WANG H.J. The Nonlinear Causal Relationship Between Environmental Regulation and Technological Innovation - Evidence Based on the Generalized Propensity Score Matching Method. Sustainability, 12, 1, 2020.

35. European Commission. Available online: https://ec.europa. eu/environment/eir/pdf/report_sk_sk.pdf (accessed on 14 June 2020).
36. SLOVAK BUSINESS AGENCY. Analysis of the use of eco-innovation and the circular economy in the SME environment, $1^{\text {st }}$ Ed.; Slovak Business Agency: Bratislava, Slovakia, 121, 2018.

37. European Commission. Available online: https://ec.europa. eu/environment/ecoap/indicators/index_en (accessed on 08 June 2020).

38. LANOIE P., LAURENT-LUCCHETTI J., JOHNSTONE N., AMBEC S. Environmental policy, innovation and performance: New insights on the porter hypothesis. Journal of Economics \& Management Strategy, 20, 3, 2011.

39. KNELLER R., MANDERSON E. Environmental regulations and innovation activity in UK manufacturing industries. Resource and Energy Economics, 34, 2, 2012.

40. DANSO,A., ADOMAKO S., AMANKWAH-AMOAH J., OWUSU-AGYEI S., KONADU R. Environmental sustainability orientation, competitive strategy and financial performance. Business Strategy and the Environment, 28, 5, 2019.

41. FLIMEL M. Selected technical innovation for a sustainable environment, 1 ${ }^{\text {st }}$ Ed.; TUKE: Presov, Slovakia, 105, 2019. 